\title{
Biometric analysis of eucalyptus forests in the five initial years of development
}

\author{
A. L. T. Fernandes, T. de M. Florêncio \& M. F. de Faria \\ University of Uberaba, Brazil
}

\begin{abstract}
This research is aimed at evaluating the effects of irrigation and mineral nutrition on the growth and production of eucalyptus (Eucalyptus grandis) cultivated in the region of Triângulo Mineiro. The experiment was conducted at the Farm School of Universidade de Uberaba, which has $850 \mathrm{~m}$ of altitude, in redyellowish Latosoil. Irrigated treatments and non-irrigated treatments with different nutritional conditions ( $25 \%, 50 \%$ and $100 \%$ of the recommended doses) were compared. It was evaluated the parameters of diameter at breast height and growth in a period of five years of conducted experiment; the final productivity of wood was also determined at the end of that period. Even though results were statistically different throughout the years, at the end of the analyzed period it was observed that irrigated treatments showed the biggest biometric values as well as the biggest rates of annual medium increment. Proximity of values may have occurred due to excessive rainfall at the local, making water more available to the non-irrigated treatments.
\end{abstract}

Keywords: commercial wood, irrigation, fertilization.

\section{Introduction}

According to FAO, Brazil is the second most forested country in the world with almost 477.77 millions of hectares, and the fourth country with the biggest area dedicated to plantation forestry. However, the country lacks adequate information and functional mechanisms. The usefulness of eucalyptus is evident: virtually all parts of the tree are exploited [3].

In order to improve the production of a eucalyptus forest, one of the techniques that could be applied by growers is irrigation, which aim is the controlled supply of water to the forest species in sufficient quantity and in an 
adequate period, complementing rainfall, as not only can irrigation benefit the growth of eucalyptus tree, but it can also reduce the cutting age and provide homogeneous development of the planted forest $[1,2]$.

All things considered, the present research aimed to evaluate different strategies of irrigation and mineral nutrition in the vegetative and productive development of eucalyptus cultivated in the conditions of Triângulo Mineiro, MG (Brazillian savannah).

\section{Material and methods}

The experiment took place in the Experimental Campus of the University of Uberaba (Farm School located at Uberaba, MG). The geographic coordinates are: Latitude $19^{\circ} 44^{\prime} 13^{\prime \prime} \mathrm{S}$, Longitude $47^{\circ} 57^{\prime} 27^{\prime \prime} \mathrm{W}$ and altitude $850 \mathrm{~m}$. The local climate is classified in the Köppen system as Aw hot, humid tropical and cold, dry winter. The annual rainfall is $1,474 \mathrm{~mm}$ and the mean annual temperature is $22,6^{\circ} \mathrm{C}$. The species evaluated was Eucalyptus grandis cultivated with and without irrigation. Different levels of mineral nutrition $(25 \%, 50 \%$ and $100 \%$ of the recommended dose) were applied in a fertirrigated system for those irrigated. For the non-irrigated nutrition was applied in the standard manner. Each portion had the dimensions: $60.0 \mathrm{~m} \times 53.5 \mathrm{~m}$. The average of the sample area was $124.6 \mathrm{~m}^{2}$. The average flow of drippers used in the experiment after field evaluations were 2. $2 \mathrm{~L} \mathrm{~h}^{-1}$. Water analysis revealed it was adequate for irrigation and soil reacquired 2 tons of dolomitic lime per hectare. Plantation occurred in October, 2003. Plant spacing was $4.0 \mathrm{~m} \mathrm{x} 1,5 \mathrm{~m}$, the formulation applied at planting 08-28-16 and of coverage 20-00-20, resulting in a total of 0.25 ton. ha $^{-1}$ and 0,2 ton. $\mathrm{ha}^{-1}$, respectively. Data were collected in zigzag from the first measurable tree, corresponding to measurements from 2004 to 2008 with annual periodicity.

For field work, it was used meter tape in $\mathrm{mm}$ scale to measure tree's circumference $1.30 \mathrm{~m}$ above ground for later conversion to diameter. Haglof electric hypsometer was used to measure heights, for the lease of samples and measuring tape to measure the sample areas. Software Statistica 6.0 was used for statistical analysis of data. The volumetric calculation required the scaling of 14 trees, 7 in the irrigated sector and 7 in the non-irrigated. The choice of trees was based on diameter at breast height. The scaling was performed by collecting two orthogonal diameters at heights of sections $0.10,0.70,1.30,2.0$ and from this on, in every meter. Trees' heights were also collected. In order to calculate the solid volume of tree, Smalian's formula was applied:

$$
V=\frac{\left(g_{1}+g_{2}\right)}{2} \times c
$$

where

$\mathrm{g}_{1}=$ base diameter

$\mathrm{g}_{2}=$ top diameter

$\mathrm{c}=$ tree's height. 
In order to obtain the solid volume of each tree, an average form factor was applied (0.4412).

Graphics of the collect data were made, featuring trend lines and the $\mathrm{R}^{2}$.

\section{Results and discussion}

The total volume of eucalyptus in 2008 and the Mean Annual Increment (MAI) per treatment is in Table 1. Biggest values of MAI $\left(77.6 \mathrm{~m}^{3} \mathrm{ha}^{-1} \mathrm{year}^{-1}\right)$ were obtained by treatment with $100 \%$ fertilized and irrigated, with total volume for

Table 1: $\quad$ Total volume in $2008\left(\mathrm{~m}^{3} \mathrm{ha}^{-1}\right)$ and Mean Annual Increment, MAI $\left(\mathrm{m}^{3} \mathrm{ha}^{-1}\right.$ year $\left.^{-1}\right)$ of eucalyptus.

\begin{tabular}{|c|c|c|c|}
\hline Treatment & Statistic & $\begin{array}{l}\text { Volume } \\
\left(\mathrm{m}^{3} \mathrm{ha}^{-1}\right)\end{array}$ & $\begin{array}{c}\text { MAI } \\
\left(\mathrm{m}^{3} \mathrm{ha}^{-1} \mathrm{year}^{-1}\right)\end{array}$ \\
\hline \multirow[t]{3}{*}{$(E-I R-A)^{1}$} & Mean: & 376.1 & 77.6 \\
\hline & CV \% & 12.7 & \\
\hline & CI 95\% & 20,2 & \\
\hline \multirow[t]{3}{*}{$(E-I R-B)^{2}$} & Mean: & 328.6 & 67.8 \\
\hline & CV \% & 22.5 & \\
\hline & CI 95\% & 35.9 & \\
\hline \multirow[t]{3}{*}{$(E-I R-C)^{3}$} & Mean: & 365.8 & 75,4 \\
\hline & $\mathrm{CV} \%$ & 9.5 & \\
\hline & CI 95\% & 15.1 & \\
\hline \multirow[t]{3}{*}{$(\mathrm{E}-\mathrm{NI}-\mathrm{A})^{4}$} & Mean: & 334.9 & 69.1 \\
\hline & $\mathrm{CV} \%$ & 16.4 & \\
\hline & CI 95\% & 26 & \\
\hline \multirow[t]{3}{*}{$(\mathrm{E}-\mathrm{NI}-\mathrm{B})^{5}$} & Mean: & 271.8 & 56 \\
\hline & CV \% & 33.5 & \\
\hline & CI 95\% & 53.3 & \\
\hline \multirow[t]{3}{*}{$(\mathrm{E}-\mathrm{NI}-\mathrm{C})^{6}$} & Mean: & 304.9 & 62.9 \\
\hline & CV \% & 20.1 & \\
\hline & CI 95\% & 32 & \\
\hline
\end{tabular}

${ }^{1}$ E-IR-A: irrigated eucalyptus with $100 \%$ of nutrition.

${ }^{2}$ E-IR-B: irrigated eucalyptus with $50 \%$ of nutrition.

${ }^{3}$ E-IR-C: non-irrigated eucalyptus with $25 \%$ of nutrition.

${ }^{4}$ E-NIR-A: non-irrigated eucalyptus with $100 \%$ of nutrition.

${ }^{5}$ E-NIR-B: non-irrigated eucalyptus with $50 \%$ of nutrition.

${ }^{6}$ E-NIR-C: non-irrigated eucalyptus with $25 \%$ of nutrition. 
that block of $376.1 \mathrm{~m}^{3} \mathrm{ha}^{-1}$. Lowest levels of MAI $\left(56 \mathrm{~m}^{3} \mathrm{ha}^{-1} \mathrm{year}^{-1}\right)$ and total volume $\left(271.8 \mathrm{~m}^{3} \mathrm{ha}^{-1}\right.$ year $\left.^{-1}\right)$ were observed in the treatment E-NIR-B. It is noteworthy that in Brazil a good management of production obtains a maximum of $50 \mathrm{~m}^{3} \mathrm{ha}^{-1}$ year ${ }^{-1}$.

Figure 1 shows eucalyptus' height with different markers referring to the annual averages and trend lines with correlation coefficients above $97 \%$, which means data are strongly correlated. During the period studied, with lines of tendency for each treatment. In 2008 there were close height values of E-IR-A (24.16 m), E-IR-C (23.69 m) and E-NIR-A $(23.25 \mathrm{~m})$. Treatment E-NIR-B had the lowest levels $(20.75 \mathrm{~m})$

The equations for each treatment (and each correlation coefficient) are listed below:

E-IR-A: irrigated eucalyptus with $100 \%$ of nutrition,

$$
y=13.239 \ln x+2,556 \quad R^{2}=0,9915
$$

E-IR-B: irrigated eucalyptus with $50 \%$ of nutrition

$$
y=13.805 \ln x+1,5742 \quad R^{2}=0,9757
$$

E-IR-C: non-irrigated eucalyptus with $25 \%$ of nutrition

$$
y=13.188 \ln x+1,7364 \quad R^{2}=0,9839
$$

E-NIR-A: non-irrigated eucalyptus with $100 \%$ of nutrition

$$
y=12.998 \ln x+1,9664 \quad R^{2}=0,9886
$$

E-NIR-B: non-irrigated eucalyptus with $50 \%$ of nutrition

$$
y=11.779 \ln x+2,236 \quad R^{2}=0,9944
$$

E-NIR-C: non-irrigated eucalyptus with $25 \%$ of nutrition

$$
y=11.513 \ln x+2,0559 \quad R^{2}=0,9957
$$

Results of Turkey's test for eucalyptus heights are in Table 2. It is observed that in 2005, 2007 and 2008 E-IR-A differed significantly from others (Table 2(A), 2(C) and 2(D)). 


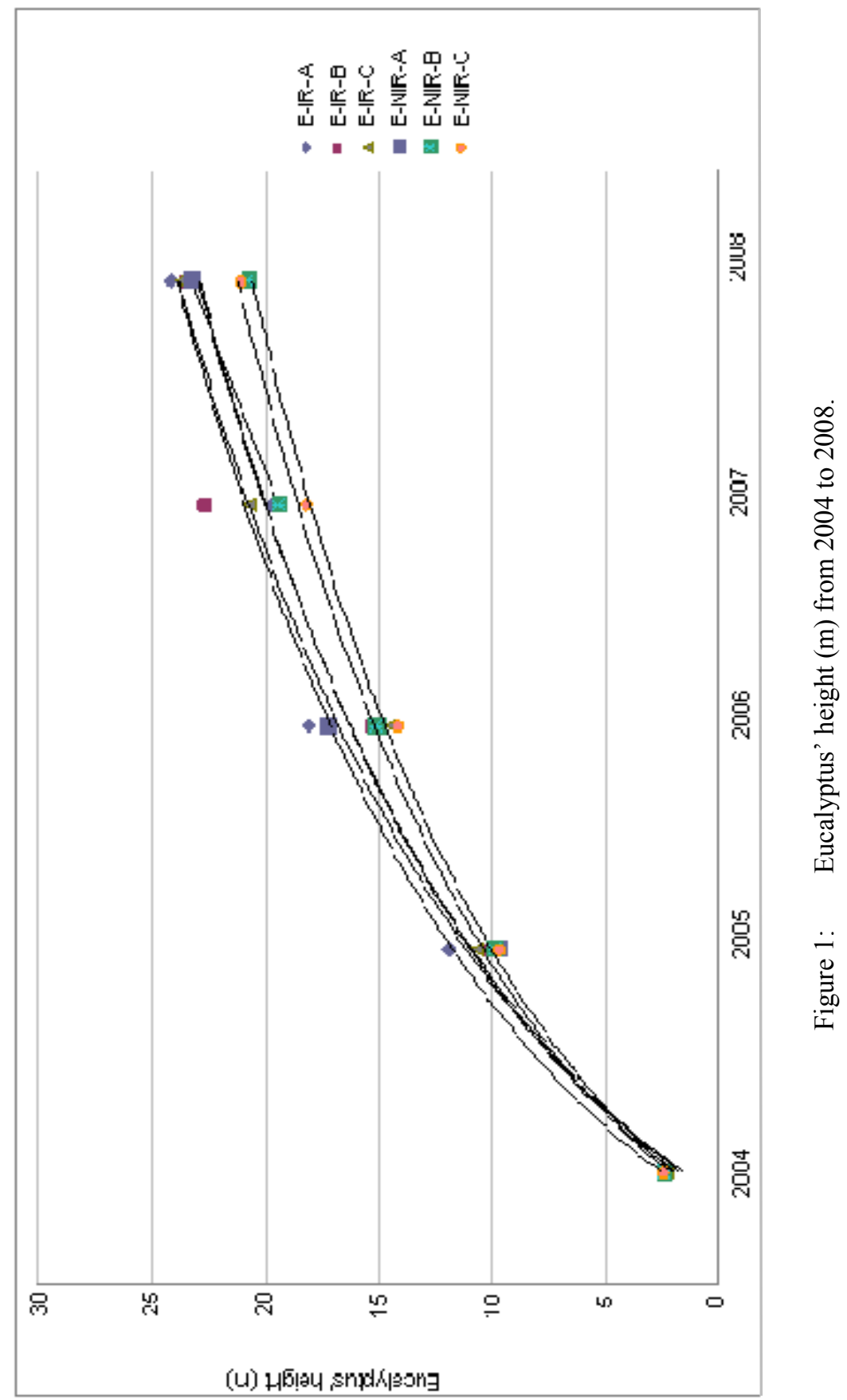


Table 2: $\quad$ Results of Tukey's test for eucalyptus' height (m).

\begin{tabular}{|c|c|}
\hline \multicolumn{2}{|c|}{$2005(\mathrm{~A})$} \\
\hline Treatment & Mean* \\
\hline$(\text { E-NIR-C })^{6}$ & $9.65625 \mathrm{a}$ \\
\hline$(\text { E-NIR-A })^{4}$ & $9.72917 \mathrm{a}$ \\
\hline$(\text { E-NIR-B })^{5}$ & $9.875 \mathrm{a}$ \\
\hline$(E-I R-B)^{2}$ & $10.17708 \mathrm{a}$ \\
\hline$(E-I R-C)^{3}$ & $10.66667 \mathrm{a}$ \\
\hline$(E-I R-A)^{1}$ & $11.88542 \mathrm{~b}$ \\
\hline \multicolumn{2}{|c|}{$2006(\mathrm{~B})$} \\
\hline Treatment & Mean \\
\hline$(\mathrm{E}-\mathrm{IR}-\mathrm{C})^{3}$ & $14.43333 \mathrm{a}$ \\
\hline$(\text { E-NIR-C })^{6}$ & $14.57604 \mathrm{a}$ \\
\hline$(\mathrm{E}-\mathrm{NIR}-\mathrm{B})^{5}$ & $15.06771 \mathrm{a}$ \\
\hline$(\mathrm{E}-\mathrm{IR}-\mathrm{B})^{2}$ & $15.23125 \mathrm{a}$ \\
\hline$(\text { E-NIR-A })^{4}$ & $17.20104 \mathrm{~b}$ \\
\hline$(\text { E-IR-A })^{1}$ & $18.0375 \mathrm{~b}$ \\
\hline \multicolumn{2}{|c|}{$2007(\mathrm{C})$} \\
\hline Treatment & Mean \\
\hline$(\mathrm{E}-\mathrm{NIR}-\mathrm{B})^{5}$ & $20.85857 \mathrm{a}$ \\
\hline$(\text { E-NIR-C })^{6}$ & $21.0871 \mathrm{ab}$ \\
\hline$(\mathrm{E}-\mathrm{NIR}-\mathrm{A})^{4}$ & $22.75797 \mathrm{ab}$ \\
\hline$(\mathrm{E}-\mathrm{IR}-\mathrm{B})^{2}$ & $23.21538 \mathrm{ab}$ \\
\hline$(\text { E-IR-C })^{3}$ & $23.78676 \mathrm{ab}$ \\
\hline$(E-I R-A){ }^{1}$ & $24.11014 \mathrm{~b}$ \\
\hline \multicolumn{2}{|c|}{2008 (D) } \\
\hline Treatment & Mean \\
\hline$(\mathrm{E}-\mathrm{NIR}-\mathrm{B})^{5}$ & $20.85857 \mathrm{a}$ \\
\hline$(\text { E-NIR-C })^{6}$ & $21.0871 \mathrm{ab}$ \\
\hline$(\mathrm{E}-\mathrm{NIR}-\mathrm{A})^{4}$ & $22.75797 \mathrm{ab}$ \\
\hline$(\mathrm{E}-\mathrm{IR}-\mathrm{B})^{2}$ & $23.21538 \mathrm{ab}$ \\
\hline$(E-I R-C)^{3}$ & $23.78676 \mathrm{ab}$ \\
\hline$\left(\right.$ E-IR-A) ${ }^{1}$ & $24.11014 \mathrm{~b}$ \\
\hline
\end{tabular}

${ }^{1}$ E-IR-A: irrigated eucalyptus with $100 \%$ of nutrition.

${ }^{2}$ E-IR-B: irrigated eucalyptus with $50 \%$ of nutrition.

${ }^{3}$ E-IR-C: non-irrigated eucalyptus with $25 \%$ of nutrition. 
${ }^{4}$ E-NIR-A: non-irrigated eucalyptus with $100 \%$ of nutrition.

${ }^{5}$ E-NIR-B: non-irrigated eucalyptus with $50 \%$ of nutrition.

${ }^{6}$ E-NIR-C: non-irrigated eucalyptus with $25 \%$ of nutrition.

${ }^{*}$ Treatment means in the same group are not statistically different from each other.

\section{Conclusion}

In 2006, E-IR-A was statistically equivalent to the average of E-NIR-A. In 2007, E-NIR-B had the minimum values whereas E-IR-A featured the maximum values. The biggest value of eucalyptus' height was 24.11 , corresponding to EIR-A in 2008 (Table 2D).

Irrigated treatments showed the highest biometric rates (height). Higher values of MAI were obtained by the irrigated treatment and $100 \%$ fertilized.

\section{References}

[1] Gruber, Y.B.G, Tavares, A.C.S., Detomini, E.R. e R.D. Coelho, 2006. Eucalipto irrigado tem de produzir mais: quanto é preciso aumentar a produtividade para custear cada sistema de irrigação. Agrianual: anuário da agricultura brasileira [1], 318-321.

[2] Lopes, J.L.W., Guerrini, I.A, Saad, J.C.C. e M.R. Silva, 2005. Efeitos da irrigação na sobrevivência, transpiração e no teor relativo de água na folha em mudas de Eucalyptus grandis em diferentes substratos. Scientia Forestalis [68], 97-106.

[3] Shimizu, J.Y., 2006. Pinus na silvicultura brasileira. Revista da Madeira [16], 4-14. 